\title{
Altered biochemical responses by rat Sertoli cells and peritubular cells cultured under simulated diabetic conditions
}

\author{
J.C. Hutson \\ Department of Anatomy, Texas Tech University Health Sciences Center, Lubbock, Texas, USA
}

\begin{abstract}
Summary. The purpose of the present study was to determine whether the secretion of androgen-binding protein and lactate by 16-day-old rat Sertoli cells is altered when these cells are cultured in simulated diabetic conditions. Incorporation of ${ }^{3} \mathrm{H}$-uridine into RNA by peritubular cells cultured in simulated diabetic conditions was also studied. The cells were exposed to various concentrations of glucose, $\beta$-hydroxybutyrate, sodium bicarbonate (to alter the $\mathrm{pH}$ of the medium), mannitol (to influence the osmolarity of the medium), or a combination of these compounds. All of the metabolic parameters when tested alone or in combination were capable of increasing lactate secretion by Sertoli cells above control values. Basal secretion of androgen-binding protein, however, was
\end{abstract}

not influenced by any individual component or when all components were tested together. FSH-stimulated levels of androgen-binding protein secretion was depressed only when the Sertoli cells were exposed to all the components simultaneously. Incorporation of uridine by peritubular cells was decreased by exposing the cells to butyrate or mannitol, while no effect was observed with glucose treatment. These results indicate that Sertoli cell and peritubular cell function can be directly altered by several specific metabolic parameters associated with diabetes.

Key words: Sertoli cells, diabetes, androgen-binding protein.
Reproductive dysfunction is commonly observed in long-term diabetic patients $[1,2]$ as well as in experimentally-induced diabetic animals [3]. Since the Sertoli cells are thought to be involved in regulating spermatogenesis, it may be hypothesized that these cells are involved in this pathogenic process. Androgen-binding protein $(\mathrm{ABP})$ [4-7], plasminogen activator [8, 9], transferrin [10], an oestrogen-like compound $[11,12]$ and lactate $[13,14]$ are all produced by Sertoli cells under the regulation of follicle-stimulating hormone (FSH). The secretion of $\mathrm{ABP}$, which has become a standard index of Sertoli cell function, is also regulated by insulin [15], retinol [15], and possibly testosterone [16-18]. Lactate secretion is potentially of great importance to the function of the seminiferous tubule since it has been shown that germ cells prefer lactate to glucose as an energy substrate [19]. However it is not known if the secretion of lactate is altered in diabetic animals.

In a previous study, it was demonstrated that levels of ABP in the epididymides of streptozotocin-induced diabetic animals were significantly higher 4 weeks after treatment than in control animals [20]. Murray et al. [21] reported that the level of $\mathrm{ABP}$ in the epididymides of streptozotocin-induced diabetic rats was only elevated 3 weeks after streptozotocin treatment; at 1, 2 and 4 weeks after treatment, the levels of ABP were normal. However it is not known whether the increased levels of ABP in the epididymides of diabetic animals are a result of increased secretion of ABP by Sertoli cells, or of decreased transport or decreased turnover of $A B P$ in the epididymis. In addition, it is not known whether the increased levels of ABP in the epididymis were a result of a direct action of altered glucose metabolism (high serum glucose levels, increased serum osmolarity or $\mathrm{pH}$, the presence of serum ketone bodies or a combination of the above) on Sertoli cells. It is possible that the effects of these metabolic imbalances on the pituitary or hypothalamus resulted in decreased levels of FSH or testosterone thereby influencing the Sertoli cells or the epididymis indirectly.

The purpose of the present study was to investigate $\mathrm{ABP}$ and lactate secretion by Sertoli cells cultured in simulated diabetic conditions. This approach provides the opportunity to study independently the direct effects of several important metabolic components of diabetes which are thought to mediate many of the side ef- 
fects of this disease. In addition this approach in vitro circumvents weight loss and glucose maintenance problems associated with streptozotocin-injected animals.

\section{Materials and methods}

\section{Culture system}

Sertoli cells and peritubular cells were isolated from 16-day-old Wistar rats and maintained in culture as previously described [22]. This isolation procedure is similar to the original procedures published by Steinberger et al. [6] and Dorrington and Fritz [23]. The purity of the cell preparations produced by this technique in this laboratory has been documented previously [22]. The cells were plated into $35 \times 10 \mathrm{~mm}$ plastic Petri dishes (Falcon Plastics, Los Angeles, California) in $1 \mathrm{ml}$ medium 199 (KC Biological, Lenexa, Kansas) plus penicillin $(100 \mathrm{units} / \mathrm{ml})$, streptomycin $(100 \mu \mathrm{g} / \mathrm{ml})$ and fungizone $(2.5 \mu \mathrm{g} / \mathrm{ml}$ ) (Gibco, Grand Island, New York). The medium for the peritubular cells was supplemented with $10 \%$ fetal calf serum (KC Biological) that had been heat inactivated for $30 \mathrm{~min}$ at $56^{\circ} \mathrm{C}$. All cells were acclimatized for $24 \mathrm{~h}$ before beginning the experiment.

\section{Experimental design}

The following media were added to the cells after a $24-\mathrm{h}$ acclimatizion period in culture: (1) medium 199, (2) minimal essential medium (MEM, Earle's base), (3) medium $199+$ an additional 27.8, 44.4 or $111.1 \mathrm{mmol}$ glucose (unmodified medium contained $5.6 \mathrm{mmol} / 1 \mathrm{glu}-$ cose), (4) medium $199+20,40$, or $60 \mathrm{mmol} / 1 \beta$-hydroxybutryate $(\beta$-OHB) (Sigma, sodium salt), (5) medium $199+7.14-40.5 \mathrm{mmol} / 1$ $\mathrm{NaHCO}_{3}$, (6) medium $199+$ mannitol (Sigma) to a final concentration ranging from $386-630 \mathrm{mOsmol}$ (control media has an osmolarity of $286 \mathrm{mOsmol}$ for medium 199 and $294 \mathrm{mOsmol}$ for MEM, or (7) $\mathrm{MEM}+111.1 \mathrm{mmol} / 1$ glucose, $60 \mathrm{mmol} / 1 \beta$-OHB and the addition of mannitol to a final concentration of $486 \mathrm{mOsmol}$. The Sertoli cells were cultured for an additional 4 days and the medium was removed from the dishes and assayed for ABP [24] with slight modifications [30]. Lactate was also measured in the medium using a kit from Sigma Chemicals, St. Louis, Missouri. Glucose was determined using a kit from Boehringer, Indianapolis, Indiana. The cells were assayed for protein [25] or DNA [26]

The peritubular cells were washed with serum-free medium and then pulsed with $10 \mu \mathrm{Ci} / \mathrm{ml}$ of ${ }^{3} \mathrm{H}$-uridine (ICN Nutritional Biochemicals, Cleveland, Ohio) for 30-240 min in serum-free medium following the 4-day treatment period. The cells were then solubilized in 1\% triton X-100 and the radioactivity in the acid insoluble fraction (precipitated with $10 \%$ trichloroacetic acid) counted in a scintillation spectrometer. Separate aliquots were assayed for protein [25] and DNA [26].

The means of the various treatment groups were each compared to the control values using Student's t-analysis. A $p$ value $\leqslant 0.05$ was considered to be statistically significant. All experiments were repeated at least twice. Each graphical point represents the mean of three to five determinations from one experiment. Each determination represents a separate culture vessel.

\section{Results}

\section{Sertoli cells}

Lactate secretion by Sertoli cells was influenced by all of the individual treatments as well as by the combined regime (Fig. 1). Glucose treatment increased lactate secretion in both FSH-stimulated cells and the unstimu-

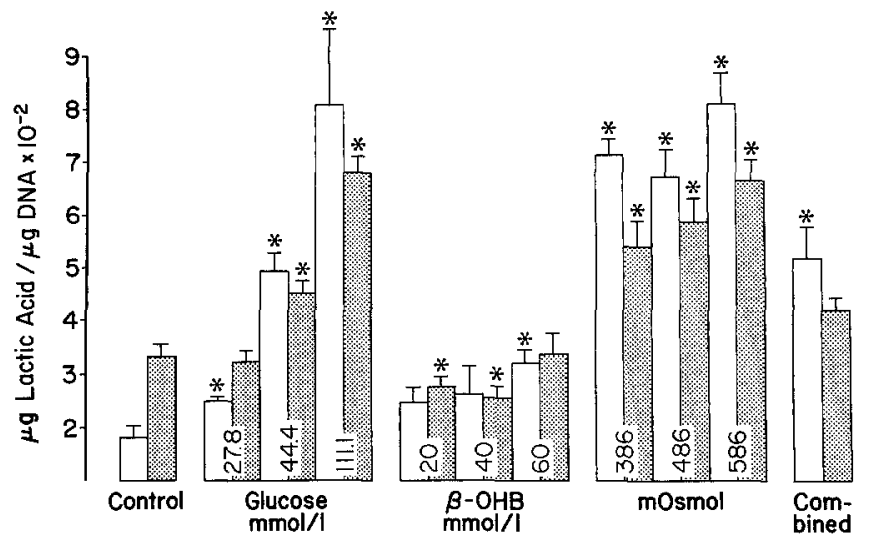

Fig. 1. Secretion of lactate in Sertoli cells exposed to high levels of glucose, $\beta$-OHB or mannitol. The FSH-induced increase in lactate, as observed in control animals, was abolished by exposing the cells to high levels of $\beta$-OHB. When all the parameters were tested in combination, the unstimulated values were significantly greater than the unstimulated values obtained from the control cells. The FSH-stimulated values were not significantly different from the FSH-stimulated values of the control cells. * indicates a statistically significant difference between the mean of the group indicated as compared to the mean of the control cells either with or without FSH treatment

Table 1. Effects of glucose on lactate secretion under isotonic conditions

\begin{tabular}{|c|c|}
\hline Treatment & $\begin{array}{l}\text { Lactate secretion } \\
\text { by Sertoli cells } \\
\text { (ug lactate/ } \mu \mathrm{g} \text { DNA) }\end{array}$ \\
\hline MEM (294 mOsmol) & $174.8 \pm 6.6$ \\
\hline $\begin{array}{l}\text { MEM plus } 111.1 \mathrm{mmol} / 1 \text { glucose } \\
(\mathrm{NaCl} \text { reduced to give osmolality } \\
\text { of } 294 \mathrm{mOsmol})\end{array}$ & $272.3 \pm 21.1^{\mathrm{a}}$ \\
\hline $\begin{array}{l}\text { MEM plus } 111.1 \mathrm{mmol} / \mathrm{l} \text { glucose } \\
(333 \text { mOsmol })\end{array}$ & $547.6 \pm 43.0^{\mathrm{a}}$ \\
\hline
\end{tabular}

Results expressed as mean \pm SEM from three culture dishes. ${ }^{\text {a }}$ Indicates a significant increase compared with MEM (294 mOsmol)

lated cells compared with control cells (Fig. 1). $\beta$-OHB at low concentrations reduced the FSH-induced increase in lactate secretion (Fig. 1). Increasing the osmolarity of the medium with mannitol increased lactate secretion in both FSH-stimulated and unstimulated cells. However, the unstimulated cells responded with the greatest percentage increase. Lactate secretion was also increased by Sertoli cells cultured in MEM +111.1 $\mathrm{mmol} / 1$ glucose in which the osmolarity was adjusted to isotonicity by reducing the concentration of $\mathrm{NaCl}$ (Table 1). Lactate secretion was severely altered by lowering the concentration of bicarbonate in the medium (Table 2). The combined regime increased lactate secretion by unstimulated cells while lactate secretion by FSH-stimulated cells was unchanged (Fig.1). The amount of glucose after 4 days in culture was only $5 \%$ less than at day 1.

ABP secretion by Sertoli cells was unaffected by individual treatment with glucose, $\beta$-OHB or mannitol. 


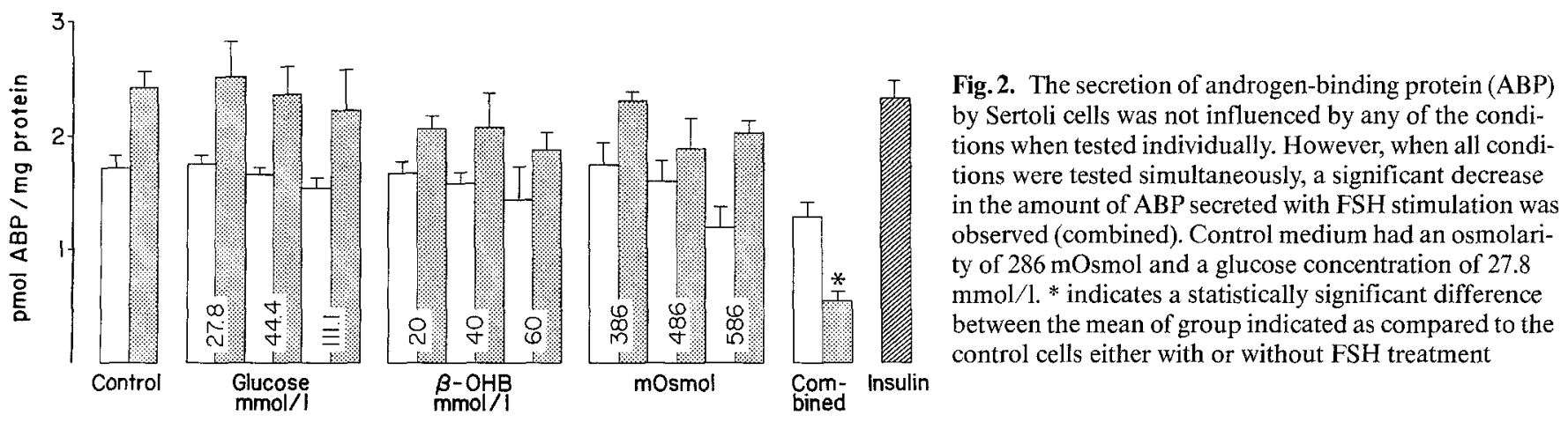

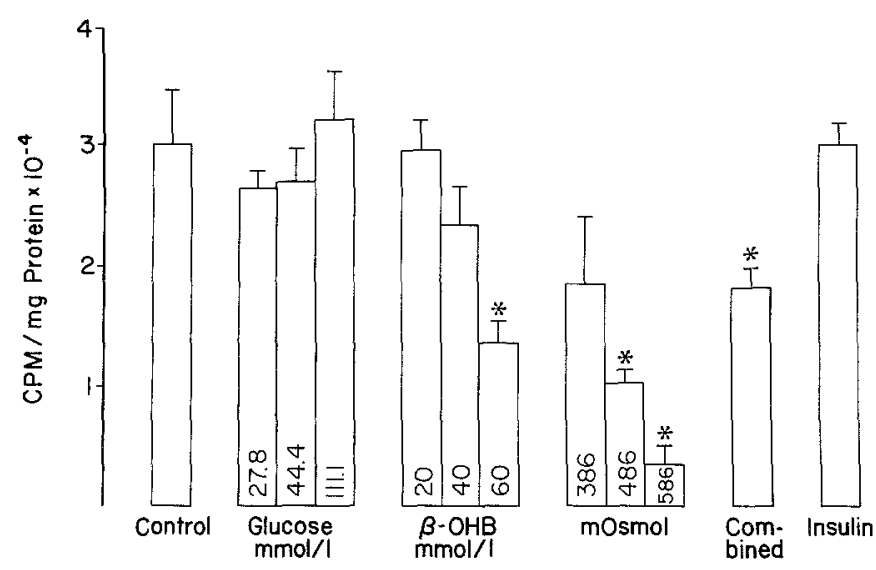

Fig.3. Uridine incorporation into acid-precipitable material in peritubular cells was altered when the cells were exposed to high levels of butyrate or mannitol. No significant change was observed when the cells were treated with high levels of glucose. The combined treatment produced a statistically significant depression in the amount of amino acids incorporated. * indicates a statistically significant difference between the mean of the group indicated as compared to the mean of the control cells

Table 2. Effect of pH on lactate secretion

\begin{tabular}{lcc}
\hline $\begin{array}{l}\mathrm{NaHCO}_{3} \\
(\mathrm{mmol} / \mathrm{l})\end{array}$ & $\mathrm{pH}$ & $\begin{array}{l}\text { Lactate secretion } \\
\text { by Sertoli cells } \\
(\mu \mathrm{g} \text { lactate/ } \mu \mathrm{g} \text { DNA) }\end{array}$ \\
\hline 7.1 & 7.08 & $22.4 \pm 1.7$ \\
11.9 & 7.22 & $73.2 \pm 8.8$ \\
16.7 & 7.34 & $49.7 \pm 5.2$ \\
21.4 & 7.42 & $88.6 \pm 3.6$ \\
26.2 & 7.45 & $112.1 \pm 6.7$ \\
30.9 & 7.50 & $104.1 \pm 3.0$ \\
35.7 & 7.54 & $106.0 \pm 13.1$ \\
40.5 & 7.74 & $82.5 \pm 4.2$ \\
\hline
\end{tabular}

Results expressed as mean \pm SEM for three culture dishes

However, when all were combined, a decrease in FSHstimulated ABP secretion was observed (Fig. 2). FSH and insulin both increased ABP secretion significantly.

\section{Peritubular cells}

The incorporation of ${ }^{3} \mathrm{H}$-uridine by peritubular cells was linear over a 4-h period and could be inhibited by actinomycin $\mathrm{D}$. Treatment with $\beta$-OHB, mannitol, or a combined regime resulted in a decrease in uridine incorporation (Fig. 3).

\section{Discussion}

Although the simulated diabetic conditions employed in these studies do not exactly mimic the diabetic condition in vivo, they do allow the individual metabolic components commonly associated with diabetes to be tested separately on cell function. Sertoli cells were particularly suitable for these studies since: (1) their function has been reported to be altered in diabetic animals $[20,21],(2)$ they are involved in reproductive processes, and (3) they can be isolated to relative purity and remain physiologically viable in culture $[6,8-11,14,15$, $22,23]$.

The most dramatic change in Sertoli cell function was observed when these cells were treated with high levels of glucose or mannitol. Although ABP secretion did not change, lactate secretion increased approximately fourfold. It is unlikely that the altered response of lactate secretion seen with glucose treatment is simply due to changes in osmolarity, since the medium supplemented with $111.1 \mathrm{mmol} / \mathrm{l}$ glucose, in which the osmolarity was maintained at isotonic levels, was also able to stimulate an increase in lactate secretion. It is not known whether an increase in lactate secretion occurs in vivo nor is it known if increased levels of lactate are deleterious to testicular function.

Although butyrate can be used as an energy substrate, it is possible that it becomes toxic to cells at high concentrations. It is unlikely that the effects of butyrate are due to altered $\mathrm{pH}$ since the sodium salt form of butyrate was used, thereby maintaining the $\mathrm{pH}$ at control levels. However, when the $\mathrm{pH}$ of the medium was altered with sodium bicarbonate, lactate secretion dropped sharply. Therefore, it appears that Sertoli cell function is sensitive to high levels of butyrate and altered $\mathrm{pH}$. However, it cannot be ruled out that sodium bicarbonate has a direct effect on Sertoli cells.

Previous studies indicated that ABP levels in the epididymis were higher than normal 3-4 weeks following streptozotocin treatment $[20,21]$. The present study 
demonstrates that cultured Sertoli cells secrete less ABP when exposed to diabetic conditions. This suggests that the altered levels of ABP in the epididymides of diabetic animals are a result of altered epididymal function. This could occur by increased rates of turnover of $A B P$ with the epididymis or altered flow of fluid out of this organ. It should be emphasized that our previous study did not demonstrate a change in the amount of $A B P$ in the epididymides of diabetic rats when the values were expressed per organ [20], suggesting that overall production of ABP was not altered. However, the levels of ABP are higher than controls when expressed per mg protein since the epididymides lose considerable weight in diabetic animals. This further implicates the epididymides in the process of reproductive dysfunction which occurs in diabetes. It should be pointed out that differences between the findings in the present study and those previously discussed $[20,21]$ could be due to differences between in vivo and in vitro environments, as well as differences in the age of the rats employed in these studies.

The peritubular cells were also influenced by simulated diabetic conditions. Uridine incorporation was depressed with $\beta$-OHB and mannitol treatments. This is an important finding since these cells are involved in Sertoli cell function [22] and also in producing part of the boundary tissue of the seminiferous tubule [27].

In conclusion, the results of these studies indicate that some of the specific metabolic conditions observed in diabetes mellitus can directly influence Sertoli cell and peritubular cell function in culture.

Acknowledgements. The author wishes to acknowledge the technical assistance of M.Rodriguez and the secretarial assistance of V.Edwards. The highly purified rat FSH was generously provided by the National Institute of Arthritis, Metabolic and Digestive Diseases, Rat Pituitary Hormone Distribution Program of the National Institutes of Health. The work was supported by grants from the National Institutes of Health (HD13990 and AM 23052).

\section{References}

1. Kolodny RC (1974) Sexual dysfunction in diabetic men. Diabetes 23: 306-309

2. Rubin A, Babbott D (1958) Impotence and diabetes mellitus. JAMA 168: 498-500

3. Rosenmann E, Palti Z, Teitelbaum A, Cohen AM (1974) Testicular degeneration in genetically selected sucrose-fed diabetic rats. Metabolism 23: 343-348

4. Fritz IB, Rommerts FG, Louis BG, Dorrington JH (1976) Regulation by FSH and dibutyryl c-AMP of the formation of androgenbinding protein in Sertoli cell-enriched cultures. J Reprod Fertil 46: $17-24$

5. Hagenas L, Ritzen EM, Ploen L, Hansson V, Neyfeh SN (1975) Sertoli cell origin of androgen-binding protein. Mol Cell Endocrinol 2: 339-350

6. Steinberger A, Heindel JJ, Lindsey JN, Elkington JSH, Sanborn BM, Steinberger E (1975) Isolation and culture of FSH-responsive Sertoli cells. Endoc Res Commun 2: 261-272

7. Fakunding JL, Tindall DJ, Dedman JR, Mena CR, Means AR (1976) Biochemical Actions of FSH in the Sertoli cell of the rat testis. Endocrinology 98: 392-402

8. Lacroix M, Smith FE, Fritz IB (1977) Secretion of plasminogen activator by Sertoli cell enriched cultures. Mol Cell Endocrinol 9: $227-236$

9. Hutson JC, Stocco DM (1981) Regulation of Sertoli cell function by thyrotropin. Biol Reprod 25: 303-306

10. Skinner MK, Griswold MD (1980) Sertoli cells synthesize and secrete transferrin-like protein. J Biol Chem 255: 9523-9525

11. Dorrington JH, Fritz IB, Armstrong DT (1976) Testicular estrogens: Synthesis by isolated Sertoli cells and regulation by FSH. In: Spilman CH, Lobl I, Kinton KI (eds), Regulatory mechanisms of male reproductive physiology, Exerpta Medica, Amsterdam, pp $63-70$

12. Tcholakian RK, Steinberger A (1979) In vitro metabolism of testosterone by cultured Sertoli cells and the effect of FSH. Steroids 33: $495-526$

13. Grootegoed JA, Jutte NHPM, Jansen R, Heusdens FA, Rommerts FFG, van der Molen HJ (1981) Biochemistry of Spermatogenesis. The supporting role of Sertoli cells. In: van der Molen HJ, Klopper A, Lunenfeld B (eds) Hormonal factors in fertility, infertility and contraception. Elsevier, Amsterdam, pp 169-183

14. Mita M, Price M, Hall PF (1982) Stimulation by FSH of synthesis of lactate by Sertoli cells from rat testis. Endocrinology 110: $1535-1541$

15. Kark JF, Griswold MD (1980) Actions of insulin and vitamin A on Sertoli cells. Biochem J 186: 1001-1003

16. Means AR, Fakunding JL, Huckins C, Tindall DJ, Vitale R (1976) FSH, the Sertoli cells, and spermatogenesis. Rec Prog Hor Res 32: 477-528

17. Elkington JSH, Sanborn BM, Martin MW, Chowdhury AK, Steinberger E (1977) Effect of testosterone propionate on ABP levels in rats hypophysectomized at different ages using individual sampling. Mol Cell Endocrinol 6: 203-209

18. Weddington SC, Hansson V, Ritzen EM, Hagenas L, French FS, Neyfeh SN (1975) Sertoli cell secretory function after hypophysectomy. Nature 254: 145-146

19. Jutte NHPM, Jansen R, Grootegoed JA, Rommerts FFG, Clausen OPF, van der Molen HJ (1982) Regulation of survival of rat pachytene spermatocytes by lactate supply from Sertoli cells. J Reprod Fertil 65: 431-438

20. Hutson JC, Stocco DM, Campbell GT, Wagoner J (1983) Sertoli cell function in diabetic, insulin treated diabetic and semi-starved rats. Diabetes 32: 112-116

21. Murray FT, Orth J, Gunsalus G, Musto NA, Weisz J, Li J, Jefferson LS, Bardin CW (1981) The pituitary-testicular axis in the streptozotocin diabetic male rat: evidence for gonadotroph, Sertoli cell and Leydig cell dysfunction. Int J Androl 4: 265-280

22. Hutson JC, Stocco DM (1981) Peritubular cell influence on the efficiency of ABP secretion by Sertoli cells in culture. Endocrinology 108: $1362-1368$

23. Dorrington JH, Roller NF, Fritz IB (1975) Effects of FSH on cultures of Sertoli cell preparations. Mol Cell Endocrinol 3: 57-70

24. Ritzen EM, French FS, Weddington SC, Neyfeh SN, Hansson V (1974) Steroid binding in polyacrylamide gels: quantitation at steady state conditions. J Biol Chem 249: 6579-6604

25. Lowry OH, Rosebrough NJ, Farr AL, Randall RJ (1951) Protein measurement with the folin phenol reagent. J Biol Chem 193: 265-275

26. Brunk CF, Jones KC, James TW (1979) Assay for nanogram quantities of DNA in cellular homogenates. Anal Biochem 92 $497-500$

27. Phieffer JC, Alger EA, Boccabella Av (1981) Origin of collagen in the peritubular boundary tissue of the rat testis. Anat Rec 199: $200 \mathrm{~A}$

Received: 3 May 1983

and in revised form: 19 September 1983

Dr. James C. Hutson

Department of Anatomy

Texas Tech University

Health Sciences Center

Lubbock, Texas 79430, USA 